\title{
VERTENTES RELIGIOSAS E A (DE)FORMAÇÃO DO FEMININO
}

\section{RELIGIOUS ASPECTS AND (DE)TRAINING OF WOMEN}

\author{
Sérgio Rogério Azevedo Junqueira ${ }^{1}$ \\ Emerli Schlogel ${ }^{2}$ \\ Claudia Kluck ${ }^{3}$
}

\section{Resumo}

A reflexão sobre as religiões e seu papel na formação do feminino teve seu início na observação de que em alguns cultos as divindades femininas desapareceram, que as mulheres são maioria na membresia das igrejas, e substancialmente força de trabalho, e que elas se submetem a liderança masculina nas igrejas sem questionar o modelo vigente. Meditar sobre a problemática indicou a Educação, e especialmente o Ensino Religioso, como espaço para promover reflexão sobre a liberdade e tolerância entre gêneros. Através de entrevistas com um grupo heterogêneo de mulheres contribuíram com detalhes da relação religião/religiões e seus aspectos formativos além de demonstrarem que questões sobre a sexualidade da mulher e relações de gênero ainda são reguladas pelas instituições.

Palavras-chave: gênero; feminino; religião.

\footnotetext{
${ }^{1}$ Professor Titular da Pontifícia Universidade Católica do Paraná, Doutor e Mestre em Ciências da Educação pela Pontifícia Universidade Salesiana (Roma/Itália). Professor do Programa de Mestrado em Educação da PUCPR. Professor do Programa de Mestrado em Teologia da PUCPR e Colaborador do Programa de Mestrado em Educação. Professor do Curso de Formação de Professores da Educação Infantil e Anos Iniciais e atua como Professor do Curso de Pedagogia na área das Metodologias de História Geografia e Ensino Religioso. Professor da Faculdade Internacional de Curitiba na área de Educação a Distância no Curso de Especialização de Metodologia do Ensino Religioso. Tem experiência na área de Educação, atuando principalmente nos seguintes temas: educação, ensino religioso, formação de professor, ciências da religião e educação confessional. Email: srjunq@gmail.com.

${ }^{2}$ Professor titular da Secretaria Municipal de Educação de Curitiba. Possui graduação em Educação Artística Licenciatura Plena em Música pela Faculdade de Educação Musical do Paraná, Bacharelado em Canto Lírico pela Escola de Música e Belas Artes do Paraná, graduação em Psicologia pela Universidade Tuiuti do Paraná, especializações em Psicoterapias de base corporal, performance do canto, pedagogia para o ensino religioso e mestrado em Educação pela Pontifícia Universidade Católica do Paraná. Professor titular - Secretaria Municipal de Educação, autônoma como psicóloga clínica e orientadora vocla do coral de Curitiba pela Fundação Cultural. Email: emerlischlogl@ hotmail.com.

${ }^{3}$ Professor titular da Secretaria de Educação de São José dos Pinhais. Graduada em Pedagogia pela Universidade Castelo Branco, especialista em Gestão Escolar (Gestão e as Possibilidades do Projeto Político-Pedagógico) pela Universidade Castelo Branco. Graduanda do curso de História da UNOPAR, tem como foco de suas pesquisas a Formação de Professores e em especial a Formação Docente para o Ensino Religioso. Email: claudiakluck@gmail.com.
} 


\begin{abstract}
The reflection on the religion and its role in shaping the female had its beginning in the observation that some cult of female deities disappeared. Women are the majority in the membership of the churches, and substantially the work force, and therefore the workforce, they are submitted to male leadership in churches without questioning the existing model. Reflect on the problems of Education stated, and especially the religious education as a space for reflection an, freedom and tolerance. Interviews were applied to a heterogeneous group of women who contributed details of the religion or religions and educational aspects. The views collected show that issues relevant to women's sexuality, and same way of people whose sexual orientation differs from the conventional, are governed by institutions and lack of personal reflections.
\end{abstract}

Keywords: gender; women; religion. 


\section{Introdução}

A constatação de que o número de mulheres, membros ou assistentes aos rituais e cultos, é superior ao número de homens indicou a observação sobre as religiões, no Brasil, e sua correlação quanto a identidade sexual de seus membros. É notório o empenho das mulheres, que são consideradas força motriz, em muitas religiões, para as práticas nas quais suas instituições se propõe estabelecer, então questionou-se de que forma as religiões influenciam na formação da mulher, e regulam as suas relações. Diante deste cenário e apesar de controversos, os temas sexualidade e religião converteram-se em pontos de reflexão.

A bibliografia encontrada sobre sexualidade é escassa quando ligada à temática religião. Contudo, em nada se pode negar a influência da Religião na formação e ainda a sua influência nas relações de gênero, em especial as femininas.

Buscando relacionar a forma como se dá a constituição do feminino vinculado à vivência junto aos aspectos do que é sagrado, engedrou-se uma série de questionamentos tentando identificar os pontos que influiriam na formação das mulheres. A partir daí foi entrevistado um grupo de mulheres heterogêneo: em idade, formação, classe social e diversidade religiosa. As respostas poderiam indicar uma melhor visão da forma como algumas vertentes religiosas existentes influenciam na formação e também na deformação do feminino.

\section{Desigualdades de Gênero}

Encontram-se diferentes concepções para a palavra gênero, porém o que consolidou a sua utilização no meio social foi a manutenção de desigualdades entre homens e mulheres. Desigualdade esta que vem sendo questionada com mais veemência a partir do século XX por feministas do mundo inteiro.

A desigualdade não biológica, mas de papéis e vantagens sociais deve ser foco de muita reflexão, pois no mundo científico, religioso e político, é possível identificar a posição subalterna da mulher, ainda que esta atue como agente transformador dos espaços de construção de mundo e ideologias, em pé de igualdade com homens.

Além das religiões, algumas disciplinas históricas contribuíram para uma distorção nas relações de gênero. Apesar do brilhantismo da filosofia alguns conceitos propalados a mais de 
2000 anos ajudaram a criar sofismas nos relacionamento entre homens e mulheres. Exemplo disso são as máximas aristotélicas que indicam a mulher como sendo por natureza inferior ao homem ou ainda que a mulher seria para o homem o que o servo é para o amo, indicando uma relação de servidão e dependência, apesar de ser fato que diferenças biológicas não sejam argumentos claros e sustentáveis para justificar as organizações desiguais criadas para manutenção do poder na vida de algumas comunidades.

\section{Desigualdade das Relações com o Sagrado}

Relações de poder são geradoras de instrumentos normativos dentro de diferentes tradições religiosas, e também fora delas, e historicamente estas relações penderam cedendo vantagens ora para mulheres ora para homens. Houveram ainda momentos em que ambos os gêneros cooperaram e resguardaram o valor mútuo, alicerçando sentimentos de auto-estima e dignidade na identificação de sua posição no mundo. A participação do feminino nas estruturas religiosas passou por diferentes formas, da adoração ao princípio feminino como elemento sagrado gerador de vida, para a negação deste como componente que conduz à sensualidade e à morte.

As religiões, em sua diversidade, apontam para o masculino com certa freqüência. Mas, nem sempre foi assim na história da humanidade. O feminino já ocupou lugar de destaque no cenário sagrado. Alguns pesquisadores afirmam, baseados em pinturas rupestres e em objetos encontrados, que quando a humanidade vivia nos períodos pré-históricos o ícone que apresentava o 'elemento criador ou deus' seria representado pela figura de uma mulher.

Foi tomado como ponto de partida para reflexão o Cristianismo tendo em vista sua representatividade no Brasil e a partir dele discorrer-se-á sobre outras religiões para ilustrar de que forma são recebidas as informações que influenciam os aspectos formativos do feminino.

\section{Raízes Judaico-cristãs}

No livro sagrado dos cristãos, a Bíblia, mais especificamente no Antigo Testamento encontram-se duas referências sobre à criação do homem e da mulher, em uma delas Deus criou macho e fêmea à sua semelhança $($ Gen. 1,27$)$ e em outro texto Deus criou Adão e dele 
tirou uma costela, e com ela formou então a mulher. (Gen. 2, 21-22). De acordo com o que apresenta Henry apud Beeke:

A mulher foi feita da costela do lado de Adão; não da sua cabeça, para não governálo; nem de seus pés, para não ser pisada por ele; mas do seu lado, para ser igual a ele, debaixo de seu braço, para ser protegida, e perto do seu coração, para ser amada.

Os textos indicados da criação da mulher comumente trazem interpretações que em geral, contribuem para a subserviência feminina nas tradições judaico-cristãs.

O Gênesis Cristão afirma que a serpente ludibriou a mulher e fez com ela comesse do fruto, bem como seu companheiro. A serpente na hermenêutica judaico-cristã é símbolo do mal, rasteja sobre a terra, portanto sobre o mais baixo, o instintivo. A partir do contato da mulher, com este animal é que, como conseqüência da desobediência da orientação divina, passa a conhecer as dores do parto, possibilitando o nascimento, porém com dor.

Como forma de ilustrar o tratamento desigual entre homens e mulheres Bello (2001) apresenta os seguintes trechos bíblicos, falando a respeito da purificação das parturientes, no Livro do Levítico, em seu capítulo 12 versos de 1 a 5 (TEB) existem instruções claras a respeito:

Javé falou a Moisés, dizendo: 'Fala aos filhos de Israel e dizendo-lhes: quando uma mulher conceber e der à luz um menino, ela ficará impura durante sete dias; ficará impura como nos dias de sua menstruação. No oitavo dia o menino será circuncidado; mas ela ficará ainda em casa durante trinta e três dias com o sangue da purificação; não tocará nenhuma coisa santa e não irá ao santuário, até que os dias de sua purificação se cumpram. Se der à luz uma menina, ficará impura durante duas semanas, como nos dias de sua menstruação, e ficará em casa durante sessenta e seis dias com o sangue da purificação.

É possível identificar forte carga machista quando impõe prazo dobrado de isolamento para mulheres que tenham concebido uma criança do sexo feminino. Este trecho escrito com vistas aos aspectos ritualísticos, tem também enfoque sanitarista por pretender tratar das causas de contaminações, tendo em vista as precárias condições do contexto no qual foi escrito.

Apesar disso é possível perceber nos primórdios do cristianismo, nas cartas atribuídas ao apóstolo Paulo, a proclamação da libertação da mulher de sua subserviência tradicional, 
sugerindo igualdade sexual em relação ao homem, já que "em Cristo não há a distinção entre macho e fêmea" (Livro de Gálatas 3,28).

Como forma de negar a posição igualitária é encontrado no trecho bíblico de I Coríntios 11, versos 7 a 10, indicação de diferentes posicionamentos, especialmente sobre usos e costumes, que tinha em mente o gênero.

Ressalte-se, porém que para analisar todo e qualquer texto sagrado é necessário observar o contexto completo: a realidade da época na qual o texto foi escrito, a cultura local e a localização geográfica, evitando assim distorções em sua interpretação, ou seja textos fora dos contextos que servem apenas de pretexto para dominação ou justificação de abusos.

Neste trecho há indicação clara sobre a necessidade da mulher cobrir sua cabeça com véu e manter os cabelos compridos. Saliente-se que Paulo - presumido autor da carta - fala à uma cidade portuária, privilegiadamente localizada em um istmo, banhada pelas águas do Golfo de Salônica e do Golfo de Corinto. Por receber navios do Oriente e do Ocidente, tornou-se um importante centro comercial da época. Esse privilégio fez dela uma cidade dissoluta onde reinava a devassidão, a luxúria e a licenciosidade. Ali a prostituição era prática comum, por conta da presença de marinheiros e viajantes de todo o mundo. As prostitutas, também para serem rapidamente identificadas pelos homens, tinham o costume de cortar ou raspar seus cabelos.

Interessante notar que esta indicação, sobre os cabelos das mulheres, é dirigida apenas e especificamente para igreja de Corinto. Não há texto bíblico, atribuído ao mesmo autor como orientação para outras comunidades cristãs nesse sentido, Porque em Corinto havia uma situação especialíssima que exigiu essa postura, porém não representava uma doutrina a ser impetrada, nem no cristianismo primitivo, nem hoje.

A carta paulina tem seu foco na situação de novas convertidas - inclusive prostitutas que eram orientadas à manter-se cobertas com o véu até que seus cabelos crescessem, diferenciando-as das que não tinham aderido ao culto cristão.

Também muito utilizado, e especialmente nebuloso, é o trecho do livro de Efésios, que versa sobre o homem ser o cabeça da mulher, utilizado amplamente para desrespeitar a mulher em seus direitos e possibilidades.

As mulheres sejam submissas aos seus maridos, como ao Senhor, porque o marido é cabeça da mulher, como Cristo é cabeça da Igreja, ele, o salvador do Corpo. Como a 
Igreja está sujeita a Cristo, assim as mulheres estejam sujeitas em tudo a seus maridos. (Carta aos Efésios 5, 22-24).

Para um completo entendimento é necessária a imersão em alguns rudimentos da fé cristã.

No original Paulo quando fala em cabeça, de acordo com a língua Grega, utilizada na época, poderia ter usado duas palavras: arché ou kephalé.

Se usasse arché denotaria autoridade, que inferiria o sentido de chefe, magistrado, governante, etc. Por sua vez kephalé significa apenas cabeça - raiz semântica da palavra cefaléia. Kephalé é ainda um termo militar que designa 'aquele que lidera, que vai à frente', não como um general, mas, sim, como o batedor, o que vai à frente no campo de batalha, e que se expõe primeiro ao perigo a fim de proteger e guiar aos que o seguirão. Assim a liderança do marido como cabeça indica a necessidade dele se expor para proteger, e também em conhecer a vontade de Deus ("o General”) para assim seguir Seus planos.

Paulo conhecia bem as duas palavras, afinal tinha sido instruído por Gamalieu, e escolheu usar deliberadamente kephalé o que indica o marido como aquele que lidera indo à frente para proteger os seus, servindo-os e dando por eles a própria vida, como Cristo fez pela igreja (ASSUMPÇÃO s.d.).

Mas, situação das mulheres no âmbito cristão não foi muito privilegiada pelos organizadores da fé, como por exemplo, S. Clemente da Alexandria afirmava que: 'Nada de calamitoso e próprio do homem, que é dotado de razão, o mesmo não se pode dizer da mulher para a qual é uma vergonha, refletir sobre a sua própria natureza.' (Paeds, II:, 2.83, pag. 186).

Durante muitos séculos, após o advento da era cristã, existiam na Europa, muitas religiões e na medida em que o cristianismo foi se alicerçando e se fortalecendo passou a ser imposto a vários povos. Ainda assim estes povos continuavam sua adoração a deuses e deusas diversas, mas com um disfarce cristão, pois as religiões antigas foram consideradas heresias. A Igreja da Idade Média tinha uma característica marcadamente patriarcal e dogmática, sem valorizar ou contrastar mais profundamente com os elementos femininos.

Ao se estabelecer a relação de poder entre os gêneros inúmeras crueldades foram sendo cometidas contra as mulheres e na 'idade das trevas' muitas foram perseguidas e executadas injustamente em nome da fé, em nome de um Deus Único, que abarcava o desejo humano de hegemonia, de supremacia, este Deus estava acima de todos os outros, portanto a morte se justificava pela manutenção da 'fé reinante'. 


\section{Raízes Islâmicas}

De acordo com Centro Cultural Beneficiente Islâmico de Foz do Iguaçu (s.d.), o Islam é parte da verdade revelada por Deus através de profetas para todo o mundo. Além de religião é apresentado como 'um sistema de vida completo'.

Os seus seguidores, chamados de muçulmanos, seguem uma religião de paz, misericórdia, perdão, e a maioria nada tem a ver com os eventos extremamente graves que ficaram associados com sua fé.

Seu livro sagrado é o Alcorão e Bukhairi, Muslim e Baihaqui apresentam-no como o um registro das palavras exatas reveladas por Deus por intermédio do anjo Gabriel ao Profeta Mohammad. Além deste também são seguidas as orientações ditadas pelos Hadiths (ou hadites) que é o conjunto das tradições relativas aos atos ou palavras de Maomé, sendo considerados a maior autoridade após o Alcorão.

Alcorão e Hadith são as principais fontes de fé e da prática de todo muçulmano. Neles são tratados todos os assuntos relacionados conosco, como seres humanos: sabedoria, doutrina, rituais e lei, enfim seu tema central é o relacionamento entre Deus e Suas criaturas.

Uma das visões sobre o feminino é apresentada por Sahih Al Bukhari (Parte 7, Hadith $\mathrm{N}^{\circ}$ 113) apud Almahdy (s.d.) que diz ser a mulher 'como uma costela; se você tentar endireitá-la, ela se quebra. Portanto, se você quer tirar proveito dela, faça-o mesmo sendo ela defeituosa'.

Almahdy (2007) pontua sobre a inferioridade feminina no Islã, apresentando o Hadith narrado por Abu Hurayra, amplamente aceito, onde mulheres são comparadas a cães e jumentos na sua capacidade de perturbar a oração. Porém existem relatos de Aisha, esposa do Profeta, redargüiu Huraya, pela mania de inventar Hadith.

Em outro Hadith consta 'aqueles que confiam seus negócios a uma mulher nunca conhecerão a prosperidade'. Segundo Fatima Mernissi, socióloga marroquina, o surgimento desse Hadith é misterioso. Abu Bakra, seu narrador, lembrou dessa frase do profeta, inédita, mais de vinte anos depois ter, supostamente, sido dita, após um conflito, que resultou na derrota de Aisha e com a perda de prestígio. Por isso teve muitos comentários e correções sobre importantes Hadith suprimidos ou ignorados - como aquele que fala de cães e jumentos.

Muitos hadiths apresentam-se claramente contrários à igualdade entre os gêneros, podendo ser chamados de discriminatórios. Almahdy (2007) apresenta, à guisa de exemplo, que as mulheres são tratadas como objetos sendo classificadas como 'brinquedo' em Kans-el- 
Ummal (Vol. 21, Hadith $\mathrm{N}^{\circ}$ 919). Vale salientar que foram encontrados comentários de pesquisadores (s.a., s.d) que consideram 'fraudes', 'fracos' ou 'muito fracos' hadiths notadamente usados para atribuir grau inferior às mulheres (KAREEM, s.d.).

Geralmente os costumes impostos pelo Islã para as mulheres parecem bastante rigorosos, mas não se pode esquecer que quando uma cultura observa a outra, precisa se desligar o máximo possível do prisma particular que marca sua própria cultura e fazer com sua visão de mundo tenha menos influênciado por sua ótica particular. Um exemplo é o que significa para uma islâmica o uso do véu, que pode tanto impor respeito quanto valorizar a figura feminina, contrariamente a visão de que seu uso significa submissão e ignorância.

No Islã também é ensinado aos homens que sejam bons com as mulheres e apesar disto alguns teólogos muçulmanos afirmam que a mulher não possui uma alma imortal, além de ser possível encontrar o pensamento de que o Islamismo é religião para o homem que pode se divorciar quando desejar e ficar com os filhos, enquanto as mulheres devem obedecer seus maridos, vestindo-se conforme o desejo destes para não perder a vida.

\section{Outros Olhares}

De modo geral as culturas tiveram seu período de preponderância do masculino sobre o feminino, e isto se fez observar no âmbito de praticamente todas as religiões. Cada uma a seu modo ditou e dirigiu o comportamento feminino. Os tempos foram mudando e a humanidade tem refletido e modificado certos comportamentos. O resultado das reflexões é que a igualdade entre homens e mulheres vem sendo buscada nas relações familiares, de trabalho e outras formas de contato com a sociedade. As reflexões sobre relações de gênero, em todas as instâncias de relacionamento, indicam a necessidade que todos se posicionem e reivindiquem mudanças, melhor dizendo, sejam responsáveis em realizar mudanças.

Nas últimas décadas está claro avanços significativos na busca do equilíbrio entre feminino e masculino. Exemplos das conquistas começam aparecer: o exercício do rabinato por 660 mulheres no mundo; a valorização de monjas budista, como é o caso da monja Cohen, brasileira que tem divulgado o Zen Budismo com muita propriedade; e como não citar Zilda Arns, responsável pela pastoral da criança, que tem mostrado ao mundo a força feminina através de um trabalho de espiritualidade vivida no social. 
Historicamente apenas os homens estudavam e discutiam textos bíblicos, atualmente mulheres estudam e contribuem com uma visão feminina à hermenêutica dos textos sagrados, sendo que em algumas igrejas evangélicas já são admitidas pastoras em suas hierarquias, como no caso de Luteranas, Metodistas, Evangelho Quadrangular e outras.

Nas religiões afro-brasileiras a importância da mulher é afirmada e demonstrada por pesquisadores, em suas diferentes manifestações: candomblé, umbanda, batuque, xangô, tambor de mina e outras. Nessas vertentes a estrutura religiosa parece mais favorável à igualdade entre os sexos, pois são encontrados Mães e Pais de Santos. Além disso existe um orixá bastante cultuado no Brasil, Oxumaré, e dele não se pode dizer se é feminino ou masculino, pois ele é as duas coisas ao mesmo tempo, metade do ano é macho e a outra metade é fêmea.

São encontradas também divindades femininas no Hinduísmo com diferentes significados, como é o caso de Kali, a deusa adorada e temida, que possui um colar de crânios humanos em torno de seu pescoço. Parvati é esposa de Shiva e representa a Paz, Lakshmi, esposa de Vishnu é a representação do Amor.

No Budismo, hoje, mulheres podem ser monjas. Na tradição Zen, as monjas têm cabelos raspados e usam quimonos sem enfeites, como o dos homens. A idéia é tornar o visual dos dois sexos semelhante, e com isto evitar a discriminação. Porém na escola budista Terra Pura, as mulheres não precisam cortar os cabelos e podem até pintar unhas de cores claras e usar jóias, e não se exige também o celibato.

Porém existem casos que clamam por ponderação e enfrentamento. Como por exemplo o ocorrido em agosto de 2002, no interior da Igreja Católica Apostólica Romana, que por intermédio do Vaticano, foi recusado o sacerdócio de sete mulheres, quatro alemãs, duas austríacas e uma americana, que foram excomungadas. Entre estas mulheres estavam Iris Müller, 72 anos, Ida Raming, 70 anos, ambas doutoradas em teologia.

A participação do feminino nas estruturas religiosas passou por diferentes formas, da adoração ao princípio feminino para a negação deste, do respeito à mulher sacerdotisa ao medo dos poderes biológicos desta. A divinização do corpo feminino, do eros e da terra cedeu lugar para a 'diabolização', a segregação e a exploração das mulheres, da sexualidade, da terra e de todos os seres que a habitam. A história da humanidade transcorre em um jogo de polaridades onde poderes femininos e poderes masculinos se contrapõem, onde o conflito se expressa através da divisão não igualitária de papéis. 
A grande parte das religiões institucionalizadas de hoje possuem raízes na patriarcado, no qual a mulher representava algo de menos valor. Como por exemplo, na literatura islâmica é possível encontrar:

Livro II. Regra no 213 - 'Está na natureza do sexo feminino tentar corromper os homens na Terra, e por esta razão os sábios jamais se abandonam às seduções das mulheres'.

Conforme Bello (2001) em seu texto sobre O Poder da Religião na Educação da Mulher:

O reformador da religião persa, Zaratustra, dizia que a mulher 'deve adorar ao homem como à divindade. Nove vezes pela manhã, de pé ante o marido, com os braços cruzados, deve perguntar-lhe: Que desejais, meu senhor, que faça?' (ZARATUSTRA apud LOI, 1988, p. 9).

Também Buda, o Iluminado, ensinava que: 'A mulher é má. Cada vez que se lhe apresente oportunidade, toda mulher pecará' (BUDA apud LOI, 1988, p. 9).

O teólogo alemão Martinho Lutero (1483-1546), responsável pela Reforma Protestante, dizia que: 'Não há manto nem saia que pior assente à mulher ou donzela que o querer ser sábia' (LUTERO apud LOI, 1988, p. 26).

Se pensarmos no Brasil, antes da invasão missionária, encontraremos nos povos indígenas mitos tipicamente masculinos e mitos tipicamente femininos, sem que necessariamente um tenha que suplantar o outro. Existe, por exemplo um mito Kayapó que se refere a origem de plantas cultivadas, este mito é essencialmente feminino e estabelece uma relação entre as mulheres e a agricultura.

\section{Opinião Feminina}

As mulheres entrevistadas tinham idade entre 36 e 82 anos, pertencentes a diferentes classes sociais, instituições religiosas e sem vínculo alguns. As questões abordaram história pessoal, individualidade, sexualidade, amor e espiritualidade, incluindo concepções religiosas como Deus, Diabo, Céu, Inferno e Pecado. 
Considerando as respostas no desenvolvimento desta pesquisa vale pontuar que muitas delas encontram a espiritualidade vinculada aos sentimentos de amorosidade e de partilha, colocando em segundo plano a institucionalização da religião.

Muitas apontam para uma experiência cotidiana e viva da sua espiritualidade: 'Quando olho para o firmamento gotejado de estrelas e penso que o brilho refletido vem de um passado longínquo, sinto uma 'saudade' estranha; quando converso noite adentro com alguém que me ensina a crescer; ao sentir o vento na minha face; no canto dos pássaros; na convivência diária com os animais; na beleza e singularidade do cosmo; nas manifestações de renovação da natureza; na constatação de um elo significativo entre o orgânico e o psíquico; na diversidade da vida; na constatação do equilíbrio entre bem e mal existente nos seres e em algumas vivências pessoais dos estados alterados da consciência'. (sem religião, 42 anos).

É marcante encontrar mulheres que servem-se daquilo que melhor responde às suas ligações com o transcedente, e com as outras pessoas, melhorando o diálogo e a vivência, por exemplo a mulher de 82 anos que diz ter se encontrado na prática do Yoga: '... em minha vida me aproximou mais do ser humano sendo útil. No momento que entrei no Yoga me tornei um instrumento de Deus. Minha doutrina também está no Bhagavad Gita, bem como na Bíblia que possuo em meu altar'.

Para algumas entrevistadas a vida e suas possibilidade se entrelaçam e são a causa da amplificação da vida espiritual. Seja na interação com a natureza, com o trabalho ou ainda em práticas ascéticas, encontram sua vida religiosa fazendo/tomando múltiplas linguagens para a sua expressão. Quando isto acontece a Bíblia e o Bhagavad Gita podem coexistir beneficamente na vida destas mulheres, uma vez que mostram-se consonantes com o caminho espiritual que optaram. Isto oportuniza a possibilidade de incluir diferentes linguagens religiosas e favorecer o diálogo com o diferente e a integração no que resta de seus antagonismos humanos.

Nas entrevistas foi perceptível que muitas se colocam a partir da opinião das instituições, omitindo sua própria percepção particular, talvez concordando sem questionamento, talvez como resultado de meditação profunda. Sabendo que espiritualidade é prática pessoal e peculiar a cada ser, guardadas as dimensões de cada existência, é possível abstrair sobre o conteúdo retido, o calado e o porquês. 
Uma das conclusões da pesquisa é de que tratando das questões que envolvem a sexualidade a força das instituições é notadamente normatizadora. Uma entrevistada católica (82 anos), afirmou:

Percebo movimentos de atraso dentro da igreja católica que se abre um pouco mais por causa dos evangélicos. As igrejas possuem a tendência de dominar, de absorver. Deveriam ter mais respeito pela sexualidade humana, dar mais liberdade. Pois é esta liberdade, dada por Deus,que possibilita às pessoas trilharem o caminho da espiritualidade.

$\mathrm{Na}$ perspectiva de uma budista de 40 anos a religião ainda manipula muito a sexualidade das pessoas, conforme relatou:

O ser humano é sexualizado e este é o ponto chave de todas as religiões e as instituições manipulam as pessoas, assim como a mídia nos manipula com os apelos sexuais a religião faz o mesmo quando proíbe coisas, por exemplo não pode evitar filhos (Igreja Católica). Evangélicos que dizem que você deve ser pudica, não podem se depilar, mulheres devem esconder o corpo. Os Hare Krishnas dizem que a pessoa só pode transar para ter filhos. Daí vem todo o resto, a partir disto a igreja manipula $[\ldots]$ seduzindo as pessoas para controlá-las.

Porém outra mulher, batista (36 anos), afirmou que sua vivência sexual e sua experiência religiosa ditada pela instituição que pertence é:

Tranqüila. Nunca me senti presa ou coagida a fazer ou não fazer algo com meu corpo por causa da religiosidade. Creio que o corpo deve ser gerenciado pela mordomia de nossas ações de cuidado e zelo; creio também que este corpo deve ser relacionar sexualmente com o membro de outro sexo após o casamento, por prazer e também para gerar filhos que é uma opinião pessoal e decisão do casal.

Nesta afirmação vemos implícita a liberdade para uso do corpo no relacionamento sexual, em contrapartida este deverá acontecer entre pessoas de sexos opostos e após o casamento, ainda que indique respeito por fazer ou não fazer de acordo com suas escolhas pessoais.

Uma mulher luterana (43 anos) disse que: 
As instituições religiosas deveriam tratar o tema sexualidade de maneira mais clara, direta e com respeito às dúvidas, medos e inseguranças que existem em torno desta questão. Não existem muitos espaços para esta discussão [...]. Deus ama a todos sem distinção e todos precisam da graça de Deus, independente de seu comportamento ou opção sexual. O que falta é clareza e sensibilidade para compreender as diferenças e todas as pessoas deveriam se sentir acolhidas dentro de sua instituição religiosa para não serem afastadas do convívio na comunidade e na fé.

Um mulher, sem vínculo com institução religiosa de 42 anos, afirmou que:

A religião na maioria das denominações nada mais é do que uma forma de manter a consciência que se submete, à preguiça, à irresponsabilidade, à submissão, à ignorância, à imaturidade, à consolação. Sendo, o sexo permitido no matrimônio, com fins de procriação e vivê-lo fora dele requer aplacar o pecado como algumas indulgências, pedidos de clemência, autoflagelação, confissões, conselhos e etc.; por conseguinte o amor se deve a Deus, a Jesus, a Virgem Maria e outros representantes da família celestial. Depois poderá o mortal dirigir seu sentimento de amor aos familiares guardando as devidas proporções, já que acima de tudo e de todos está Deus. É perceptível a profunda contradição entre os dogmas e a moral estabelecida pela religião institucionalizada; sexo e amor são instâncias bipartidas e sem nenhuma interação para a elevação do humano. A questão da sexualidade precisa ser compreendida e sentida como um caminho para a conectividade com o sagrado, visto que é através do exercício da sexualidade que o ser humano adentra a matéria e passa a viver nesta dimensão. A religião como instituição deveria empreender um projeto de emancipação da sexualidade humana através da amorosidade, da responsabilidade, do respeito entre os gêneros e diante das escolhas pessoais dos indivíduos.

Outra mulher budista (45 anos), explicou que:

No budismo, não há nada nem ninguém culpado por algo, ou errado ou certo. A nossa relação com a sexualidade vai depender da nossa visão de mundo. O ideal é praticarmos a sexualidade tendo em conta os resultados das nossas ações. Verificar se o que fazemos vai fazer alguém sofrer. O ponto é esse. Em todas as nossas ações, esse é o ponto a ser observado... e verificar a nossa motivação. 
As questões são abordadas de maneiras diferentes, porém, é perceptível a concepção pessoal em consonância com os ditâmes das instituições, nas respostas tanto daquelas com vínculos quanto das que se consideram sem religião.

Para uma mulher de 64 anos,católica, com leitura psicanalítica:

Não se deve discriminar espaço feminino nas coisas religiosas. Em Belém, quem mais trabalha no Sírio são os homens executivos, pobres, imbuídos no espírito. Não vejo diferença entre homens e mulheres na religião. Torço para que se dê passos mais largos em direção ao respeito aos gays e lésbicas. Ninguém nasce homem ou mulher. Foram meus pais que me disseram que eu era menina. Homossexualidade não é doença, são pessoas iguais a todas, porém que sofrem muita rejeição. Tenho muito respeito e torço para que as religiões se abram para recebê-los.

Sobre a reflexão a respeito homossexualidade a maioria das mulheres tem um discurso a favor do respeito e da liberdade para com a vivência sexual de cada um.

A entrevistada acima, como psicanalista de abordagem freudiana, apontou para a construção dos papéis sexuais dados pela cultura e família, por isto afirmou que foram seus pais que formaram a consciência de pertencimento a uma categoria sexual. Trata-se de uma psicóloga de Belém do Pará que foi criada nos moldes do catolicismo apostólico romano, e que o segue atualmente, porém desenvolveu sua própria experiência espiritual que inclui práticas cotidianas de meditação.

A mulher budista (40), criada na igreja católica, diz que na catequese recebeu um modelo de Deus castigador... Então ela O via como um ser mau, e fazia sentir muito medo Dele, vivia pedindo desculpas e rezando pelos pecados que havia cometido, o que resultou no afastamento da religião. Na adolescência ficou sem crenças e após pesquisar várias religiões e visitar locais, como a igreja quadrangular, candomblé, conheceu o espiritismo, gostou muito, mas nunca se aprofundou nele. Atualmente, segue a religião budista. Esta mulher apontou para pequenos avanços de sua própria tradição:

O espaço feminino era nada e hoje é mínimo e pessoas de orientação sexual diferente não são bem vindos. No budismo até bem pouco tempo foi permitido às mulheres frequientar o templo e conhecer o sutra de lótus e se estivessem menstruadas eram consideradas impuras, não podiam entrar ou manusear os objetos de culto. Atualmente isto mudou, aqui no Brasil, em outros lugares não saberia dizer. 
A entrevistada luterana (43 anos) afirmou que:

Creio que a mulher consegue ser um esteio na questão religiosa por ser mais apaziguadora, intermediadora e tem uma compreensão diferenciada em muitas questões pertinentes à religiosidade. Infelizmente, em parte por questões culturais a mulher ainda não ocupa muitos espaços em cargos importantes dentro da Igreja mas onde ela está atuando com certeza tem feito diferença por emitir opiniões mais avançadas sobre muitas questões e que tem contribuído para um avanço nas discussões dentro da igreja tradicional. Já em algumas denominações ela é simplesmente uma seguidora sem voz e que se submete a doutrinas que não lhe permitem pensar ou agir de maneira diferente ou que respondam à suas necessidades. Desconheço uma situação onde exista espaço para as pessoas homossexuais ou que exerçam algum ministério dentro da comunidade,mas teoricamente se diz que todas as pessoas tem espaço na Igreja independente de sua opção sexual pois a palavra de Deus é para todos. Penso que de maneira alguma as pessoas homossexuais devam ser discriminadas ou afastadas do convívio na comunidade de fé pois em todas as situações deve prevalecer o amor incondicional. O respeito deve ser mútuo sem causar escândalo ou empecilho para os membros da Igreja podendo desta forma realizar um trabalho abençoado na comunidade. É um longo caminho e nada fácil, requer muito discernimento, sensibilidade e atenção especial da Igreja.

Esta entrevistada pertencente à Igreja Evangélica de Confissão Luterana do Brasil iniciou sua experiência religiosa quando ingressou no ensino confirmatório aos 12 anos. No período de 2 anos fez amizades dentro do grupo que viria ser a continuidade para sua participação e atuação dentro do grupo de juventude, onde realmente viveu intensamente sua espiritualidade. Foram mais ou menos 4 anos de muitas atividades como encontros semanais, acampamentos, retiros, intercâmbios com outras comunidades, jogos e estudos bíblicos. Foi neste período que afirmou ter reconhecido em Cristo Seu Senhor e Salvador, anunciador sobre-comum do amor e da aceitação incondicional.

Uma entrevistada que é estudante de Taoísmo (28 anos) afirmou sobre as questões de sexualidade que:

Os taoistas acreditam que a energia sexual tem propriedades criativas e rejuvenescedoras além do seu papel na concepção da vida humana. Então, quando não se pretende procriar, pode-se atuar com outras aplicabilidades para essa energia: 
curar órgãos internos e glândulas, aumentar a capacidade cerebral e abrir os centros e canais da fisiologia energética como preparação para vivências espirituais.

A questão da mulher e das pessoas cuja orientação sexual difere da convencional, na opinião da maioria das respondentes, é regulada pela instituição e não passa por reflexões pessoais. Assim aceitam os ditames da instituição sobre o assuntos.

De maneira geral, é perceptível que as mulheres que tinham vínculo com religião desde a infância e que buscaram inteirar-se de outras expressões religiosas, ainda que permanecendo na religião de origem, expressam suas reflexões pessoais se distanciando, muitas vezes, do que a sua instituição religiosa apregoa. A maioria destas mulheres não concorda com a discriminação sofrida, por conta da orientação sexual, sofrida no interior das instituições religiosas.

\section{Considerações Finais}

Ao relacionar a constituição do feminino através do sagrado houve um prévio questionamento visando identificar quais pontos influiriam na formação de mulheres. Tornouse inconteste a influência que as diversas vertentes religiosas tem na formação e/ou deformação do feminino.

Houve condições para perceber, através dos depoimentos, que mesmo aquelas que optam pelo não vínculo direto, tem afirmados modelos de dominação e subordinação em relação ao homem. Os sentimentos que os modelos religiosos passados e atuais despertam nas mulheres, não é de saciedade e faz com que continuem buscando respostas espirituais para suas existências.

A participação feminina, como força motriz das religiões, é brilhantemente justificada pela mulher luterana de 43 anos, por que 'a mulher consegue ser um esteio na questão religiosa por ser mais apaziguadora, intermediadora e tem uma compreensão diferenciada em muitas questões pertinentes à religiosidade'.

Estas constatações não encerraram o processo reflexivo sobre o tema, do contrário indicaram urgência em encontrar um caminho diferente para as futuras gerações, ou um ritmo diferente de passo, e nisso a Educação é especialmente indicada. 
Os princípios norteadores da Educação de respeito à liberdade e apreço à tolerância, como afirma o quarto parágrafo do artigo $3^{\circ}$ da LDB 9394/96 (BRASIL, 1996), indicou que a Educação é sim um caminho profícuo para a empreitada de formar mulheres, e também homens, como um arsenal de pessoas livres, respeitosas e destemidas quanto ao diferente.

No momento exato em que a Educação é acusada por fomentar ações homofóbicas, mais especificamente através da disciplina de Ensino Religioso, se faz urgente uma consideração criteriosa a respeito do papel da Educação na transmissão de valores sobre a diversidade, sexualidade e religiões. Apesar do descompasso das instituições religiosas no sentido de discutir religião e orientação sexual a escola ainda é um lugar, minimamente, isento e conta com a figura do docente que facilitará a abertura deste lócus privilegiado de mudança de pontos de vista.

Ao questionar aspectos religiosos e as relações de gênero se abre a possibilidade em discutir sexualidade e relações dos genêros, perspassando o ideário religioso, como uma forma em entender e aprender com o que é diferente, e propõe a reflexão sobre um universo carregado de simbolismos, que na maioria das vezes é legitimado como mundo da hegemonia masculina.

Entre outros espaços formativos se mostra interessante utilizar-se do Ensino Religioso, como ambiente propício para considerações a respeito da Sexualidade, e assim dar abertura ao caminho que as ciências tem trilhado, por mais este viés e quiçá definitivamente será deliberado o respeito e o combate à discriminação a partir do conhecimento e da desmistificação.

\section{Referências}

ALMAHDY, S. Como as Mulheres são Tratadas no Islamismo. Disponível em: $<$ http://solascriptura-tt.org/Seitas/TratamentoMulheresNoIslamismo-Almahdy.htm> Acesso em: 27 abr. 2008.

ASSUMPÇÃO, W. Família Equilibrada, Igreja Abençoada - Parte I. Disponível em: <http://www.wandadeassumpcao.com.br/artigos/familia1.htm> Acesso em: 22 abr. 2008. 
BEEKE, J. A Criação da Mulher. s.d. Disponível em: $<$ http://www.monergismo.com/textos/antropologia_biblica/criacao_mulher.htm> Acesso em: 10 ago 2009.

BELLO, J. L. P. O poder da religião na educação da mulher. Pedagogia em Foco, Rio de Janeiro, 2001. Disponível em: <http://www.pedagogiaemfoco.pro.br/mulher02.htm> Acesso em: 23 abr. 2004.

BÍBliA DE REFERÊNCIA. V. T. Thompson. Português. Bíblia Sagrada. Edição Contemporânea. São Paulo. Vida, 1995.

BRASIL. Lei n. 9394/96, de 20 de dezembro de 1996. Lei de diretrizes e bases da educação nacional.

CEDI - Centro de Estudo e Divulgação do Islã. A Mulher No Islã "Paeds, II:, 2.83, pag. 186". Disponível em: <http://www.islam.org.br/a mulher_no islam.htm> Acesso em: 22 jun. 2007.

CENTRO Cultural Beneficiente Islâmico de Foz do Iguaçu. Compreenda o Islã e os Muçulmanos. Disponível em:

<http://www.islam.com.br/islam/compreendo/compreendo6.htm> Acesso em 02 fev. 2008.

KAREEM, K. A. List of weak and forged hadith related to women's issues. Disponível em: <http://islamic-answers.com /list_of_weak_and_forged_hadith_related_to_women_s_ issues> Acesso em: 22 maio 2008.

LOI, I. A mulher. São Paulo: Jabuti, 1988.

TRADUÇÃO ECUMÊNICA DA BÍBLIA (TEB). São Paulo. Edições Loyola, 1994. 